in our second study (25\%) was markedly lower than that sampled in our first study $(75 \%)$. It is possible that this may have contributed to the reduction of effect in the second study. Nothen $e t$ al found that family history of schizophrenia had no effect on genotype distributions. However, the possibility remains that their patients differed from ours with respect to treatment response or to some other as yet undetermined variable.

Nothen et al point out correctly that the controls in the French sample were not in Hardy-Weinberg equilibrium and showed an excess of heterozygotes (though $\chi^{2}$ is in fact 5.47 and not 8.7). However, the Cardiff controls did not show significant departure from Hardy-Weinberg equilibrium and nor did the further set of 98 controls typed in Cardiff. Moreover, we should remember that the significant excess of homozygotes seen in the patients as compared with Hardy-Weinberg expectations is not dependent upon the distribution of genotypes seen in the controls. Furthermore, the difference between patients and controls remains significant when the French controls are removed from the analysis $\left(\chi^{2}=6.8, p=0.009\right)$. In view of the fact that the French controls were all members of hospital staff, whereas the controls in the first Cardiff study were married in members of families seeking DNA diagnosis for non-psychiatric diseases, we too wondered whether these differences might reflect heterozygote advantage. However, when we compared a sample of members of staff from our Institute, all of whom are graduates $(n=37)$, with our other controls $(n=129)$, no significant homozygosity effect $(p=0.66)$ or other differences were found and no significant departures from HardyWeinberg equilibrium were observed (both $p$ values $=0.9$ )

Morell is correct to point out that our findings could have resulted from allelic dropout. We have also considered this possibility and have retyped our sample with a second set of primers placed internally to the first. The results we obtained were identical to those obtained from the first set of primers.

$$
\begin{aligned}
& \text { M J OWEN*† } \\
& \text { R MANT*+ } \\
& \text { PASHERSON*† } \\
& \text { Department of Psychological Medicine* and }
\end{aligned}
$$

\section{Severity of chest disease in CF patients in relation to their genotypes}

Al-Jader et al ( $\mathcal{F}$ Med Genet 1992;29:883-7) assessed severity of lung disease by calculating \% predicted values for $\mathrm{FEV}_{1}$ and FVC and comparing single values in subjects of different ages, as did Johansen $e t a l^{1}$ in a similar study. Although in widespread use, this method has deficiencies, especially when analysing lung function data over time. The widely held assumption that a given \% predicted value means the same for subjects of different ages is untrue; older subjects will have a lower $\%$ predicted value than younger ones with comparable lung function. ${ }^{2}$

Furthermore, older survivors with any CF genotype are likely to have milder disease and better lung function. This source of bias influences the plot of $\mathrm{FEV}_{1}$ against time presented by Al-Jader $e t$ al and Johansen $e t$ al. ${ }^{\prime}$ In each case the plot first shows a linear fall in FEV, with time followed by an upturn in the curve for older patients. On the basis of this, Johansen et al ${ }^{1}$ claim the $\Delta \mathrm{F} 508$ heterozygotes have less severe lung disease. However, if the three most extreme data points from the oldest patients are excluded from the graph in both studies, then the relation between $F E V_{\text {, }}$ and time becomes approximately linear, and the difference between heterozygotes and homozygotes is no longer apparent.

We have examined longitudinal lung function data in Grampian CF patients. ${ }^{3}$ Forty-four patients were $\Delta \mathrm{F} 508$ homozygotes, nine were $\mathrm{G} 551 \mathrm{D} / \Delta \mathrm{F} 508$ compound heterozygotes, and 18 patients had other genotypes, including nine heterozygotes for $\Delta$ F508 and an unidentified mutation. Annual spirometric data were retrospectively collected from case notes. A regression line was constructed for each patient's lung function data over time, and a slope value calculated. A logarithmic transformation was applied to linearise the data, and mean slope values were calculated for each group. Mean slope values of the groups were not significantly different. Therefore, we too were unable to show differences in severity of lung disease in CF patients with different mutations.

Al-Jader et al suggest that patients with the genotype $621+1, G \rightarrow T / \Delta F 508$ may have more severe disease and $\mathrm{R} 117 \mathrm{H}$ heterozygotes milder disease, but differences in lung function data were not significant. Moreover, only four patients with $\mathrm{R} 117 \mathrm{H}$ were studied, so it is not valid to make any general inference about that mutation. There is a need for different centres to pool data before firm conclusions can be made about clinical features of CF patients with rare mutations.

$$
\begin{array}{r}
\text { G E PACKE } \\
\text { Department of Thoracic Medicine, } \\
\text { City Hospital, Urquhart Road, } \\
\text { Aberdeen AB9 } 8 A U, U K . \\
\text { Z H MIEDZYBRODZKA } \\
\text { J C S DEAN } \\
\text { Medical Genetics, Medical School, } \\
\text { Foresthill, } \\
\text { Aberdeen AB9 2ZD, UK. }
\end{array}
$$

1 Johansen HK, Nir M, Hoiby N, et al. Severity of cystic fibrosis in patients homozygous and heterozygous for delta F508 mutation. Lancet heterozygous for

2 Miller MR, Pincock AC. Predicted values: how should we use them? Thorax 1988;43:265-7.

3 Packe GE, Miedzybrodzka ZH, Russell G, et al. Comparison of clinical featurs in cystic fibrosis patients with different genotypes. Thorax 1992;47:866P
This letter was shown to Dr Al-Jader et al who reply as follows.

We were interested to learn that Packe $e t$ al ${ }^{1}$ were unable to show differences in severity of lung disease with different mutations by analysis of longitudinal data; this finding is in keeping with ours ${ }^{2}$ by analysis of cross sectional data.

The observation that, "older subjects have lower \% predicted values for respiratory function tests than younger ones with comparable lung function"' was unknown to us. However, the paper would seem to refer to an adult population ( 30 to 70 years) in whom the objective was to define abnormality. We see no problem with the use of this method $\left(\mathrm{FEV}_{1}\right.$ and $\mathrm{FVC}, \%$ predicted by vitalograph) versus age in our cross sectional study of patients aged 5 to 31 years. In addition to the use of respiratory function tests, we also scored chest $x$ ray appearances (by ChrispinNorman score) in four age bands: $<5.0$ years, 5.0-9.9, 10.0-14.9, and $>15.0$ years. Patients homozygous and heterozygous for $\Delta F 508$ showed similar declines in score; from this, similar declines in lung function could be inferred. ${ }^{4}$

We question whether it is valid to remove the three most extreme data points from the oldest patients as plotted on the FEV $\%$ predicted graphs of Johansen $e t a l^{5}$ and from our graphs and to consider the remaining data without these points. As we discussed in our paper, ${ }^{2}$ the upturn in the curves for the heterozygous patients could relate to the death of the more severely affected patients and survival of those with a more advantageous genotype. Further work will establish whether this is so.

Regarding our patients who are heterozygous for $621+1 G \rightarrow T(n=7)$ and heterozygous for $\mathrm{R} 117 \mathrm{H}(\mathrm{n}=4)$, we accept that differences in lung function are not significant. We agree that there is a need for multicentre studies to examine the clinical features of CF patients with unusual mutations.

$$
\begin{array}{r}
\text { L N AL-JADER } \\
\text { H C RYLEY } \\
\text { S MAGUIRE } \\
\text { G OWEN } \\
\text { S ELBORN } \\
\text { M C GOODCHILD } \\
\text { Institute of Medical Genetics, } \\
\text { Cystic Fibrosiology, } \\
\text { Depart, } \\
\text { Department of Child Health, } \\
\text { University Hospital of Wales, } \\
\text { Heath Park, } \\
\text { Cardiff CF4 4XW, UK. }
\end{array}
$$

1 Packe GE, Miedzybrodzka ZH, Russell G, et al. Comparison of clinical features in cystic fibrosis patients with different genotypes. Thorax sis patients with
$1992 ; 47: 866 \mathrm{P}$

2 Al-Jader LN, Meredith AL, Ryley HC, et al. Severity of chest disease in cystic fibrosis patients in relation to their genotypes. $\mathcal{F} \mathrm{Med}$ Genet 1992;29:883-7.

3 Miller MR, Pincock AC. Predicted values: how should we use them? Thorax 1988;43:265-7.

4 Coates AL, Boyce P, Shaw DG, et al. Relationship between the chest radiograph, regional lung function studies, exercise tolerance, and clinical condition in cystic fibrosis. Arch Dis Child 1981;56:106-11.

5 Johansen HK, Nir M, Hoiby N, et al. Severity of cystic fibrosis in patients homozygous and heterozygous for delta F508 mutation. Lancet 1991;337:631-4. 